\title{
Effect of arbuscular mycorrhizas on crown rot (Phytophthora cactorum) in micropropagated strawberry plants
}

\author{
Mauritz Vestberg, Hanna Palmujoki, Päivi Parikka and Marjatta Uosukainen
}

\begin{abstract}
Vestberg, M.', Palmujoki, H.', Parikka, P. ${ }^{2}$ \& Uosukainen, M'. 1994. Effect of arbuscular mycorrhizas on crown rot (Phytophthora cactorum) in micropropagated strawberry plants. Agricultural Science in Finland 3: 289-295. ('Laukaa Research and Elite Plant Unit, Agricultural Research Centre of Finland, FIN-41340 Laukaa, Finland and ${ }^{2}$ Institute of Plant Protection, Agricultural Research Centre of Finland, FIN-31600 Jokioinen, Finland.)
\end{abstract}

\begin{abstract}
Preliminary studies were conducted on the effect of arbuscular mycorrhizal fungi (AMF) against strawberry crown rot caused by Phytophthora cactorum (Leb. \& Cohn) Schroet. A micropropagated strawberry cultivar susceptible to the disease, 'Jonsok', was either inoculated with the Finnish AMF strains Glomus mosseae (Nicol. \& Gerd.) Gerdemann \& Trappe V57, G. hoi Berch \& Trappe V98 and G. fistulosum Skou \& Jakobsen V128, or it was left uninoculated. AMF inoculation at the beginning of the weaning stage, five weeks before the establishment of the pot or field experiment, did not decrease crown rot severity in either of the experiments. In the pot experiment, on the contrary, AMF lowered the plant health index when $P$. cactorum was added to the substrate in the form of infected plant residues. Results are discussed in relation to soil-borne vs. foliar disease, phosphorus concentration of the growth substrate and influence of weather conditions.
\end{abstract}

Key words: Fragaria x ananassa, 'Jonsok', Glomus fistulosum, Glomus hoi, Glomus mosseae

\section{Introduction}

The arbuscular mycorrhizas (AM) represent a means of biological control against soil-borne diseases. The effect of these fungi against crown rot in strawberry, a shoot disease caused by Phytopthora cactorum (Leb. \& Cohn) Shroet., has not been studied earlier, but promising results against related soil-borne pathogens have been achieved, for example against $P$. cinnamomi in Chamaecyparis lawsoniana (BÄRTSCHI et al. 1981), against $P$. megasperma in soybean (CHOU and SCHMITTHENNER 1974) and against $P$. parasitica in citrus (DAvis and Menge 1980). Although AMF often has been found to increase plant resistance against soil-borne diseases, shoot and foliar diseases have rather increased in severity following mycorrhizal inoculation (DEHNE 1982, ShARMA et al. 1992).

$P$. cactorum is a common soil-inhabiting fungus in temperate regions causing two kinds of disease symptoms in cultivated strawberry, Fragaria $x$ ananassa Duch. The fungus causes leather rot of the berries and serious crown rot (MAAS 1984). Affected strawberry plants wilt suddenly and the base of petioles and the upper parts of the crowns turn dark brown. Roots are not affected until the aboveground parts die. Crown rot of strawberry is difficult to control because the fungus tends to spread easily through the soil during wet periods. Residues of diseased plants also serve 
as sources of inoculum. Resting spores of the fungus may remain viable for many years in the soil (MAAS 1984).

In Finland, $P$. cactorum was found to cause severe crown rot of strawberry 'Jonsok' in 1990. Preliminary studies (PARIKKA 1991) have shown considerable differences in disease susceptibility among Finnish strawberry cultivars. In addition to 'Jonsok', 'Mari' and 'Zefyr' are also very susceptible to the disease. However, the pathogen may induce relatively weaker symptoms or even remain symptomless in the more resistant cultivars (e.g. 'Senga Sengana'). Micropropagated strawberry plants have proven more susceptible to the disease than runner plants (PARIKKA, unpublished).

The objective of this study was to evaluate the effect of three Finnish AMF strains on crown rot in micropropagated strawberry. The results presented here are preliminary. The study is part of a European collaboration research programme of COST810 where strawberry is one of the model plants chosen for evaluating the effects of mycorrhizas against diseases. Irish investigators are studying strawberry red core disesase caused by $P$. fragariae Hickman using the same AMF strains as in the present study.

\section{Material and methods}

\section{Plant material and mycorrhizal inoculation}

Prior to use in pot or field experiments, micropropagated in vitro rooted plantlets of strawberry (Fragaria x ananassa Duch.) cultivar 'Jonsok', which is particularly susceptible to $P$. cactorum, were inoculated with three AMF strains of Finnish origin. The strains were Glomus mosseae (Nicol. \& Gerd.) Gerdemann \& Trappe strain V57, $G$. hoi Berch \& Trappe strain V98 and G. fistulosum Skou \& Jakobsen strain V128. In earlier screening experiments, all strains had improved the growth of strawberry (VESTBERG, unpublished, WiLliams et al. 1992). The strawberry plantlets were inoculated at the Laukaa Research and Elite Plant Unit in April 1993 and raised in 0.251 plastic Vefi pots containing a mixture of steam sterilized peat, sand and perlite $(2: 1: 1)$. The peat of the mixture was given $5 \mathrm{~g} \mathrm{l}^{-1}$ Dolomite lime (SAXO Oy, Finland), and the whole mixture was fertilized with $0.5 \mathrm{~g} \mathrm{l}^{-1}$ Osmocote, a controlledrelease fertilizer (8-9 months, $18 \mathrm{~N}$ : $11 \mathrm{P}: 10 \mathrm{~K}$, Sierra UK Ltd). Inocula $(1 \mathrm{ml})$ were placed in the planting hole prior to strawberry transplantation.

\section{Culture of $P$. cactorum}

P. cactorum was isolated by P. Parikka from a diseased stem base of strawberry originating from a strawberry nursery at Pälkäne, Finland. The fungus was cultured on potato dextrose agar (PDA). To induce sporangia, three-week-old cultures growing in Petri dishes were flooded with autoclaved distilled water. After one week of flooding, sporangium and zoospore production was abundant, and a suspension containing on average $55 \times 10^{3}$ propagules $\mathrm{ml}^{-1}$ was used in the pot experiment.

\section{Establishment of pot experiment}

By the end of the weaning stage, at five-weeks of age (end of May 1993), the strawberry plants were transported to the Institute of Plant Protection, where they were replanted in 0.361 plastic pots containing a peat-sand mixture (2:1). The peat of the mixture was given $8 \mathrm{~g} \mathrm{l}^{-1}$ Dolomite lime, $0.5 \mathrm{~g} \mathrm{l}^{-1}$ finely ground limestone and $0.5 \mathrm{~g}$ $\mathrm{l}^{-1}$ of a commercial compound fertilizer $(11 \mathrm{~N}: 11 \mathrm{P}$ : $20 \mathrm{~K}$, Kemira Oy, Finland) for peat. The mixture was fertilized with $2 \mathrm{~g} \mathrm{l}^{-1}$ controlled-release fertilizer Osmocote Plus (8-9 months).

The experiment had a randomized complete block design with four replicates and five plants per treatment and replicate. The plants were inoculated with $P$. cactorum by two methods; overwintered leaves and stem residues contaminated with the fungus were ground finely and mixed into the substrate ( $2-3 \%$ on a volume basis), or the fungus was pipetted to the centre of the strawberry rosette in a water suspension. Two control treatments were used, one with neither AMF nor 
P. cactorum inoculation. In the second control, no AMF inoculation was performed but $P$. cactorum was applied as infected stem and leaf residues. For each plant, $2 \mathrm{ml}$ of the suspension containing approximately $1.1 \times 10^{5}$ propagules was applied. The plants were raised in a glasshouse at $22^{\circ} \mathrm{C}$ and $12-16$ hour daylength.

\section{Establishment of field experiment}

The field experiment was carried out at a strawberry nursery at Pälkäne, Finland. The field was prepared for cultivation in 1992 and given 600 $\mathrm{kg} \mathrm{ha}^{-1}$ of a compound fertilizer (10N:7P:14K, Kemira Oy, Finland), whereafter the field was planted with strawberry. In 1992, the field had a natural infection with severe outbreaks of strawberry crown rot. The experiment was established at the end of May in 1993 by planting five-weekold AMF inoculated or uninoculated strawberry plants, 40 plants per treatment, at spots where the disease had killed strawberries in the previous year. The experiment had a completely randomized design. Plants were not fertilized during the experiment in 1993. The soil was a silty finesand with pH 5.8 and an ammonium acetate-extractable nutrient content of $1335 \mathrm{mg} \mathrm{l}^{-1} \mathrm{Ca}, 246$ $\mathrm{mg}{ }^{1-1} \mathrm{Mg}, 134 \mathrm{mg} \mathrm{l}^{-1} \mathrm{~K}$ and $12.5 \mathrm{mg} \mathrm{l}^{-1} \mathrm{P}$ as determined by standard soil analysis.

\section{Assessment of AMF colonization}

AMF colonization of strawberry roots was determined prior to planting in the pot or the field experiment and at the end of both experiments. Root samples were stained with $0.05 \%$ trypan blue according to the method of PHILLIPS and HAYMAN (1970), and AMF colonization was determined under a stereomicroscope using the grid-line intersect method (GiovanNeTti and Mosse 1980).

\section{Assessment of plant health and growth parameters}

Strawberry shoot health was estimated weekly in both experiments as a health index on a rating scale from 0 to $6(0=$ wilted and dead, $6=$ com- pletely healthy). Crown internal health was estimated at the end of both experiments on a rating scale from 0 to 3 ( $0=$ strong discoloration and rotting, 3 = no discoloration). Symptoms in roots were estimated as a root health index from 0 to 5 $(0=$ small roots, strong rottening; $5=$ large and branching root system, light roots). Shoot and root fresh and dry weights were measured at the end of the experiments.

\section{Results}

\section{Pot experiment}

When $P$. cactorum was applied in a water suspension to the strawberry rosette, wilting symptoms due to the fungus appeared very rapidly. Two weeks after inoculation, on average $58 \%$ of the plants had wilted and died due to the disease. One week later, the corresponding percentage was $62 \%$ after which, however, no more plants died due to the disease. Plant health index reached its minimum two weeks after $P$. cactorum inoculation, whereafter a certain recovery of the plants was observed. Mycorrhizal treatment had no significant effect on plant health (Fig. 1). At the end of the experiment, the colonization percentages had dropped remarkably as compared with initial levels, especially in strains V98 and V128 (Table 1). Also the eventual crown internal and root health indices following $P$. cactorum suspension treatment dropped (Table 3).

When plant residues with $P$. cactorum were mixed into the substrate, disease incidence was very low with only four wilted plants, all AMF treated. All AMF treatments, and V128 in particular, lowered the plant health index eventually (Fig. 1). Strain V98 and V128 significantly lowered shoot fresh weight and also tended to lower root fresh weight as compared with $P$. cactorum treatment only, but the differences in dry weights were negligible. At the end of the experiment, the colonization percentage had dropped strongly in strain V128, only slightly in strain V98 and remained unchanged in strain V57 (Table 1). Especially in strain V128, the crown internal and the root health indices dropped (Table 3). 


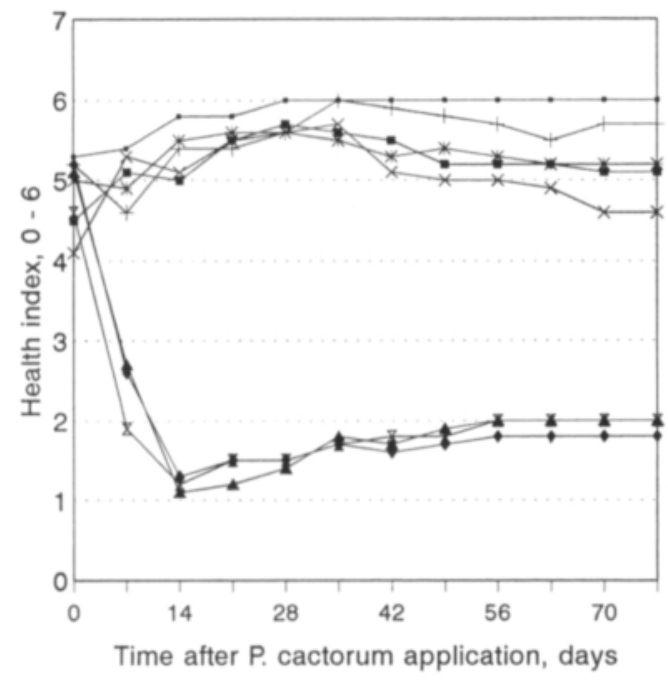

Time after P. cactorum application, days

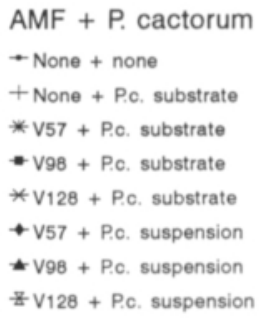

Fig. 1. Effect of arbuscular mycorrhizal inoculation at the beginning of the weaning stage and challenge inoculated with $P$. cactorum five weeks later on the subsequent health index $(0$ to $6 ; 0=$ dead, $6=$ healthy) of micropropagated strawberry 'Jonsok' in a pot experiment. Duration 11 weeks.

Table 1. Effect of arbuscular mycorrhizal inoculation at the beginning of the weaning stage and challenge inoculated with $P$. cactorum five weeks later on AMF colonization percentage and on shoot and root fresh and dry weights of micropropagated strawberry 'Jonsok'. Duration 11 weeks. Values in columns marked with the same letter do not differ significantly at $\mathrm{P}=0.05$ according to Duncan's multiple range test.

\begin{tabular}{|c|c|c|c|c|c|c|c|}
\hline \multicolumn{4}{|c|}{ Inoculation } & \multirow{3}{*}{$\begin{array}{c}\text { Shoot } \\
\text { fresh } \\
\text { weight } \\
\mathrm{g}\end{array}$} & \multirow{3}{*}{$\begin{array}{l}\text { Shoot } \\
\text { dry } \\
\text { weight } \\
\text { g }\end{array}$} & \multirow{3}{*}{$\begin{array}{c}\text { Root } \\
\text { fresh } \\
\text { weight } \\
\mathrm{g}\end{array}$} & \multirow{3}{*}{$\begin{array}{c}\text { Root } \\
\text { dry } \\
\text { weight } \\
\text { g }\end{array}$} \\
\hline \multirow[t]{2}{*}{$\mathrm{AMF}$} & \multirow{2}{*}{$\begin{array}{l}\text { Phytophthora } \\
\text { cactorum }\end{array}$} & \multicolumn{2}{|c|}{ Colonization, \% } & & & & \\
\hline & & Start & End & & & & \\
\hline None & None & 0 & 0 & $18.5 \mathrm{ba}$ & $3.8 \mathrm{ba}$ & $20.3 \mathrm{a}$ & $2.9 \mathrm{a}$ \\
\hline None & Soil & 0 & 0 & $18.5 \mathrm{ba}$ & $4.4 \mathrm{a}$ & $18.5 \mathrm{ba}$ & $2.8 \mathrm{a}$ \\
\hline V57 &, & 19.2 & 22.9 & $17.5 \mathrm{ba}$ & $4.5 \mathrm{a}$ & $17.0 \mathrm{bac}$ & $3.0 \mathrm{a}$ \\
\hline V98 & $"$ & 52.0 & 37.6 & $14.4 b$ & $3.3 \mathrm{ba}$ & $14.7 \mathrm{c}$ & $2.4 \mathrm{a}$ \\
\hline V128 & , & 62.4 & 11.4 & $14.5 b$ & $4.2 \mathrm{a}$ & $14.9 \mathrm{bc}$ & $2.9 \mathrm{a}$ \\
\hline V57 & Suspension & 19.0 & 13.4 & $4.6 \mathrm{c}$ & $2.6 \mathrm{~b}$ & $3.3 \mathrm{~d}$ & $0.9 \mathrm{~b}$ \\
\hline V98 &, & 52.0 & 15.5 & $4.9 \mathrm{c}$ & $2.4 \mathrm{~b}$ & $3.2 \mathrm{~d}$ & $0.8 \mathrm{~b}$ \\
\hline V128 & ," & 62.4 & 10.1 & $4.5 c$ & $2.6 b$ & $2.3 \mathrm{~d}$ & $0.8 b$ \\
\hline
\end{tabular}

\section{Field experiment}

Despite severe disease outbreaks in the previous year, the strawberry plants showed few disease symptoms in 1993. Only three plants wilted, all AMF treated. AMF inoculation did not affect the plant health index (Fig 2). However, at the end of the experiment, the AMF treatments seemed slightly (not statistically significantly) to increase the plant height, the number of leaves per plant (data not shown) and especially the root health index (Table 3). On the other hand, G. fistulosum V128 in particular tended to decrease both shoot and root dry weights (Table 2). Prior to planting, plants used in the field experiment showed colonization percentages of $43 \%, 70 \%$ and $59 \%$ for the strains V57, V98 and V128, respectively. At the end of the experiment, the 
Table 2. Effect of arbuscular mycorrhizal inoculation at the beginning of the weaning stage on AMF colonization percentage and on shoot and root fresh and dry weights of strawberry 'Jonsok' in a field experiment with naturally occurring $P$. cactorum infection. Duration 10 weeks. Values in columns marked with the same letter do not differ significantly at $\mathrm{p}=0.05$ according to Duncan's multiple range test.

\begin{tabular}{|c|c|c|c|c|c|c|}
\hline \multirow{2}{*}{$\begin{array}{l}\text { AMF } \\
\text { inoculation }\end{array}$} & \multicolumn{2}{|c|}{ Colonization, \% } & \multirow{2}{*}{$\begin{array}{c}\text { Shoot } \\
\text { fresh } \\
\text { weight } \\
\mathrm{g}\end{array}$} & \multirow{2}{*}{$\begin{array}{c}\text { Shoot } \\
\text { dry } \\
\text { weight } \\
\mathrm{g}\end{array}$} & \multirow{2}{*}{$\begin{array}{c}\text { Root } \\
\text { fresh } \\
\text { weight } \\
\mathrm{g}\end{array}$} & \multirow{2}{*}{$\begin{array}{c}\text { Root } \\
\text { dry } \\
\text { weight } \\
\text { g }\end{array}$} \\
\hline & Start & End & & & & \\
\hline None & 0.0 & 7.8 & $75.3 \mathrm{ba}$ & $12.4 \mathrm{a}$ & $10.2 \mathrm{ba}$ & 1.6a \\
\hline V57 & 69.8 & 13.9 & $67.6 \mathrm{ba}$ & $11.7 \mathrm{a}$ & $10.2 \mathrm{ba}$ & $1.4 \mathrm{a}$ \\
\hline V98 & 69.8 & 24.6 & $77.2 \mathrm{a}$ & $9.6 a$ & $12.9 \mathrm{a}$ & $1.6 \mathrm{a}$ \\
\hline V128 & 59.0 & 12.2 & $52.2 \mathrm{~b}$ & $7.8 \mathrm{a}$ & $8.5 \mathrm{~b}$ & $1.2 \mathrm{a}$ \\
\hline
\end{tabular}



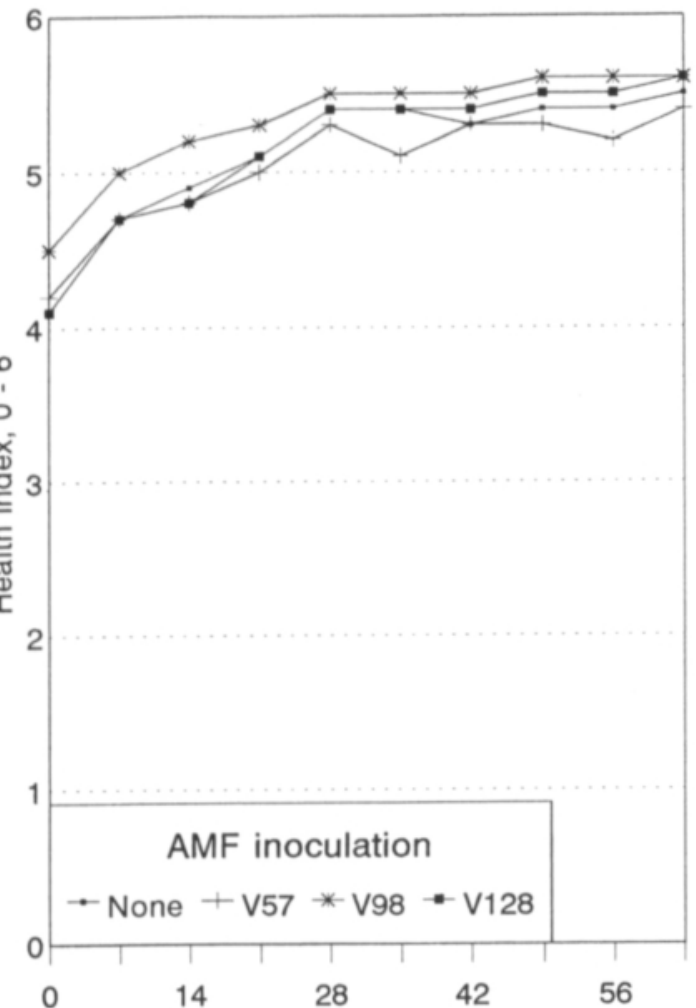

Time after onset of experiment, days

Fig. 2. Effect of arbuscular mycorrhizal inoculation at the beginning of the weaning stage on the subsequent health index ( 0 to $6 ; 0=$ dead, $6=$ healthy) of micropropagated strawberry 'Jonsok' in a field experiment with naturally occurring $P$. cactorum infection. Duration 10 weeks.
Table 3. Effect of arbuscular mycorrhizal inoculation at the beginning of the weaning stage on crown health index ( 0 to $3 ; 0=$ strong rottening, $3=$ no discoloration) and root health index ( 0 to $5 ; 0=$ small roots, strong rottening, $5=$ large, light roots) of micropropagated strawberry 'Jonsok' challenge inoculated with $P$. cactorum in a pot experiment and subjected to natural $P$. cactorum infection in a field experiment.

\begin{tabular}{|c|c|c|c|}
\hline \multicolumn{2}{|c|}{ Inoculation } & \multirow{2}{*}{$\begin{array}{c}\text { Crown health } \\
0-3\end{array}$} & \multirow{2}{*}{$\begin{array}{c}\text { Root health } \\
0-5\end{array}$} \\
\hline AMF & P. cactorum & & \\
\hline \multicolumn{4}{|c|}{ Pot experiment } \\
\hline None & None & 2.8 & 4.2 \\
\hline None & Substrate & 2.2 & 3.6 \\
\hline V57 & ," & 2.2 & 3.2 \\
\hline V98 & ," & 2.3 & 3.5 \\
\hline V128 & ," & 1.9 & 2.8 \\
\hline V57 & Suspension & 0.7 & 1.0 \\
\hline V98 & ," & 0.7 & 1.0 \\
\hline V128 &, & 0.7 & 1.0 \\
\hline \multicolumn{4}{|c|}{ Field experiment } \\
\hline None & Natural infection & 2.9 & 2.1 \\
\hline V57 & , $\quad, "$ & 2.7 & 2.8 \\
\hline V98 & ," & 2.8 & 2.5 \\
\hline V128 & $"$ & 2.8 & 2.6 \\
\hline
\end{tabular}

percentages had dropped remarkably in all three strains, but were still higher than that of the uninoculated plants, which were infected by indigenous AMF (Table 2). 


\section{Discussion}

The interactions between AMF and plant disease have been summarized as follows (SHARMA et al. 1992): (1) AM infection in general protects plants from soil-borne fungi. (2) Higher nutrient concentrations in mycorrhizal plants make such plants more susceptible to foliar pathogens. (3) No definite relationship appears to exist between bacterial infection and mycorrhization. (4) Pre-mycorrhizal infection of transplanting crops protects the plants from nematode infection.

In this study, inoculation with arbuscular mycorrhizal fungi prior to challenge inoculation with Phytophthora cactorum did not decrease the severity of crown rot in strawberry. In fact, at least one of the AMF strains (V128) clearly seemed to predispose the plants to $P$. cactorum (Fig. 1). Although the number of wilted plants was low, four in the pot experiment and three in the field experiment, when P. cactorum was applied to the substrate, it may be no coincidence that the wilted plants all originated from AMF treated plots. Several studies have shown that AMF may increase the severity of shoot and foliar diseases (SCHÖNBECK 1979, DeHNE 1982). SCHÖNBECK and DEHNE (1981) suggested that the increased susceptibility of AMF inoculated plants to shoot disease was due rather to an enhanced development of the pathogen than to an increased frequency of infection. In soybean, Ross (1972) found that mycorrhizal inoculation increased considerably internal stem discoloration caused by Phytophthora megasperma var sojae.

According to DEHNE (1982) the increased susceptibility of AMF inoculated plants to shoot dis- eases seems to correlate with nutritional aspects. This was demonstrated by DAVIS and MENGE (1980) for the root rot disease of citrus. AMF partly controlled this disease at $15 \mathrm{mg} \mathrm{P} \mathrm{l}^{-1}$ soil $^{-1}$ but had no effect at $56 \mathrm{mg} \mathrm{P} \mathrm{kg}^{-1} \mathrm{soil}^{-1}$. In the present study, the amount of phosphorus in the growth substrate used in the pot experiment after the weaning stage was approximately $37 \mathrm{mg} \mathrm{l}^{-1}$ substrate apart from a certain amount of $\mathrm{P}$ coming from the controlled-release fertilizer. This amount of $\mathrm{P}$ was apparently too high to induce maximum AM colonization in strawberry roots, which is indicated by the fact that AMF colonization dropped dramatically towards the end of both experiments.

The present study shows the difficulty of getting "moderate" and uniform disease outbreaks, which would make interpretation of results easier. This was true in both the pot and the field experiment. Although the field experiment was established at a site of high disease potential, the disease level was very low in 1993. This was due to the prevailing weather conditions during the growing season. Transplantation of the strawberry was followed by a very cool and quite dry four-week period. During this time, hardly any growth occurred in strawberry. Strawberry crown rot is favoured by warm and wet weather conditions during the infection stage, while hot and dry weather is optimal for the crown rot devolpment (MAAS 1984).

Acknowledgements. The authors wish to express their gratitude to Kittilä nursery for the permission to establish the field experiment in their field. The study was supported financially by the Finnish Ministery of Agiculture and Forestry, which is gratefully acknowledged.

\section{References}

Bärtschi, H., Gianinazzi-Pearson, V. \& Leigh, I. 1981. Vesicular-arbuscular mycorrhiza formation and root rot disease (Phytophthora cinnamomi) development in Chamaecyparis lawsoniana. Phytopathologishe Zeitschrift 102: 213-218.

Chou, L.G. \& Schmitthenner, A.F. 1974. Effect of Rhizobium japonicum and Endogone mosseae on soybean root rot caused by Pythium ultimum and Phytophthora megasperma var. sojae. Plant Disease Reporter 58: 221225.

DAVIS, R.M. \& MENGE, J.A. 1980. Influence of Glomus fasciculatus and soil phosphorus on Phytophthora root rot of citrus. Phytopathology 70: 447-452.

DEHNE, H.W. 1982. Interaction between vesicular-arbuscular mycorrhizal fungi and plant pathogens. Phytopathology 72: 1115-1119. 
Giovannetti, M. \& Mosse, B. 1980. An evaluation of techniques for measuring vesicular arbuscular mycorrhizal infection in roots. New Phytologist 84: 489500.

MAAS, J. L. 1984. Compendium of strawberry diseases. American Phytopathological Society. St.Paul, Minnesota. $138 \mathrm{p}$.

ParikKa, P. 1991. Phytophthora cactorum on strawberry in Finland. Nordisk Jordbruksforskning 73: 121.

Phillips, J.M. \& HaYMAN, D.S. 1970. Improved procedures for clearing and staining parasitic and vesicular arbuscular mycorrhizal fungi for rapid assessment of infection. Transactions of the British Mycological Society 55: 158-161.

Ross, J.P. 1972. Influence of Endogone mycorrhiza on Phytophthora root rot of soybean. Phytopathology 62 :
896-897.

SCHÖNBECK, F. 1979. Endomycorrhiza in relation to plant disease. In: Shippers, B. \& Gams, W. (eds.). Soil-borne Plant Pathogens. Academic Press, London. p. 271-280.

- \& DEHNE, H.-W. 1981. Mycorrhiza and plant health. Gesunde Pflanzen 33: 186-190.

Sharma, A.K., Johri, B.N. \& Gianinazzi, S. 1992. Vesicular-arbuscular mycorrhizae in relation to plant disease. World Journal of Microbiological Biotechnology 8: 559-563.

Williams, S.C.K., Vestberg, M., Uosukainen, M., DODD, J.C. \& JEFFRIES, P. 1992. Effects of fertilizers and arbuscular mycorrhizal fungi on the post vitro growth of micropropagated strawberry. Agronomie 12: 851-857.

\title{
SELOSTUS
}

\section{Arbuskelimykorritsasienten vaikutus mansikan tyvimätään}

\author{
Mauritz Vestberg, Hanna Palmujoki, PÄIVi Parikka ja Marjatta Uosukainen
}

Maatalouden tutkimuskeskus

\begin{abstract}
Arbuskelimykorritsasienten (AM-sienten) vaikutusta mansikan tyvimätään selvitettiin alustavissa tutkimuksissa vuonna 1993. Mansikan tyvimätä, aiheuttaja Phytophthora cactorum, todettiin Suomessa virallisesti ensimmäisen kerran vuonna 1990 'Jonsok' lajikkeella. Tauti on vaikeasti torjuttavissa ja mikrolisätyt mansikan taimet on todettu rönsytaimia taudille alttiimmiksi. Arbuskelimykorritsasienet ovat yleisiä maasieniä, jotka elävät symbioosissa useimpien viljelykasvien kanssa. Näiden sienten avulla on voitu mm. vähentää eräiden Phytophthora-sienten aiheuttamia maalevintäisiä kasvitauteja, mutta AM-sienten vaikutus lehtitauteihin on ollut vähäistä.
\end{abstract}

AM-sienten vaikutusta mansikan tyvimätään tutkittiin maatalouden tutkimuskeskuksen Laukaan tutkimus- ja valiotaimiaseman ja kasvinsuojelun tutkimuslaitoksen välisenä yhteistyönä. Laukaan tutkimus-ja valiotaimiasemalla tuotettiin 'Jonsok' mikrotaimia, joihin siirrostettiin kolme erilaista AMS-kantaa viisi viikkoa ennen niiden altistamista $P$. cactorum-sienelle astia- tai kenttäkokeessa.

Astiakoe toteutettiin kasvinsuojelun tutkimuslaitoksella. Mansikat tartutettiin tyvimätäsienellä kahdella eri tavalla. Ensiksi taudinaiheuttajasientä sisältäviä kasvinjätteitä sekoitettiin mansikan kasvualustaan ja toiseksi sienen viljelmästä tehtyä suspensiota tiputettiin mansikan kasvupisteen päälle. Kun taudinaiheuttaja sekoitettiin kasvu- alustaan, oireet jäivät hyvin vähäisiksi ja mykorritsasienet jopa hieman huononsivat taimien kuntoa. Tiputuksen seurauksena lähes $60 \%$ taimista lakastui kahden viikon sisällä, eikä $\mathrm{AM}$-sienien todettu vähentävän tautia.

Kenttäkoepaikaksi valittiin Pälkäneellä sijaitseva mansikkatila, jossa vuonna 1992 esiintyi runsaasti tyvimätää. Vuonna 1993 tautioireita ei kuitenkaan juuri esiintynyt. Tilalle istutetusta kokeesta kuoli yhteensä vain kolme tainta, jotka kaikki olivat mykorritsakäsiteltyjä. AM-sienet eivät parantaneet taimien kuntoa, mutta lisäsivät hieman taimien korkeutta ja paransivat juuriston kuntoa. Toisaalta eräs mykorritsakanta selvästi vähensi sekä verson että juurten kasvua.

Alustava tutkimus osoitti, että mahdollisuudet käyttää mykorritsasieniä biologisena torjuntakeinona mansikan tyvimätää vastaan ovat pienet. Tämä tulos on yhtenevä aikaisempien ulkomaisten tulosten kanssa, joiden mukaan mykorritsa saattaa jopa lisätä versotautien ankaruutta. Vaikka mansikan tyvimädän aiheuttajasieni on maassa elävä, on taudin pääasiallinen iskeytymispaikka mansikan maanpäällinen tyvi ja juuristo alkaa tuhoutua vasta mansikan taimen kuoltua. Täten juuristoa infektoiva mykorritsasieni ei pysty torjumaan versoston kautta iskeytyvää maalevintäistä sienitautia. 